This is an Open Access article, distributed under the terms of the Creative Commons Attribution licence (http://creativecommons.org/licenses/by/4.0/), which permits unrestricted re-use, distribution, and reproduction in any medium, provided the original work is properly cited.

\title{
Dividing the Land: Time and Land Division in the English North Midlands and Yorkshire
}

\author{
Seren Griffiths ${ }^{1} @$, Robert Johnston ${ }^{2}$, Rowan May ${ }^{3}$, David $\mathrm{McOMish}^{4}$, \\ Peter Marshall ${ }^{4}{ }^{\oplus}$, Jonathan Last ${ }^{4}$ and Alex Bayliss ${ }^{4}$ \\ ${ }^{1}$ Department of History, Politics and Philosophy, Manchester Metropolitan University, UK \\ ${ }^{2}$ Department of Archaeology, University of Sheffield, UK \\ ${ }^{3}$ ArcHeritage, Sheffield, UK \\ ${ }^{4}$ Historic England, York (McOmish), London (Marshall, Bayliss), and Portsmouth \\ (Last), UK
}

Land divisions are ubiquitous features of the British countryside. Field boundaries, enclosures, pit alignments, and other forms of land division have been used to shape and delineate the landscape over thousands of years. While these divisions are critical for understanding economies and subsistence, the organization of tenure and property, social structure and identity, and their bistories of use bave remained unclear. Here, the authors present the first robust, Bayesian statistical chronology for land division over three millennia within a study region in England. Their innovative approach to investigating long-term change demonstrates the unexpected scale of later 'prehistoric' land demarcation, which may correspond to the beginnings of increasing social bierarchy.

Keywords: land division, field systems, Bayesian modelling, long-term change, radiocarbon

\section{INTRODUCTION}

From later prehistory to the present day, land divisions (field systems, boundaries, trackways, and enclosures) are ubiquitous features of the British countryside, providing evidence for cultivation, animal husbandry, political power, and social identity. Land divisions are remarkably common, with around seventy per cent of the English landscape currently organized within field systems (McOmish, 2011). Even the highest and most remote landscapes have been divided into parcels, while lower-lying regions are shaped by deep histories of enclosure and agricultural transformation (Figure 1). This makes England, and Britain and Ireland more broadly, an important region in which to observe and understand the relations between land enclosure, agriculture, and society from a long-term perspective.

The time-depth of these preserved land divisions has been long recognized. Eighteenth- and nineteenth-century antiquarians, such as William Stukeley and Richard Colt Hoare, first identified later 'prehistoric' field systems (Johnston, 


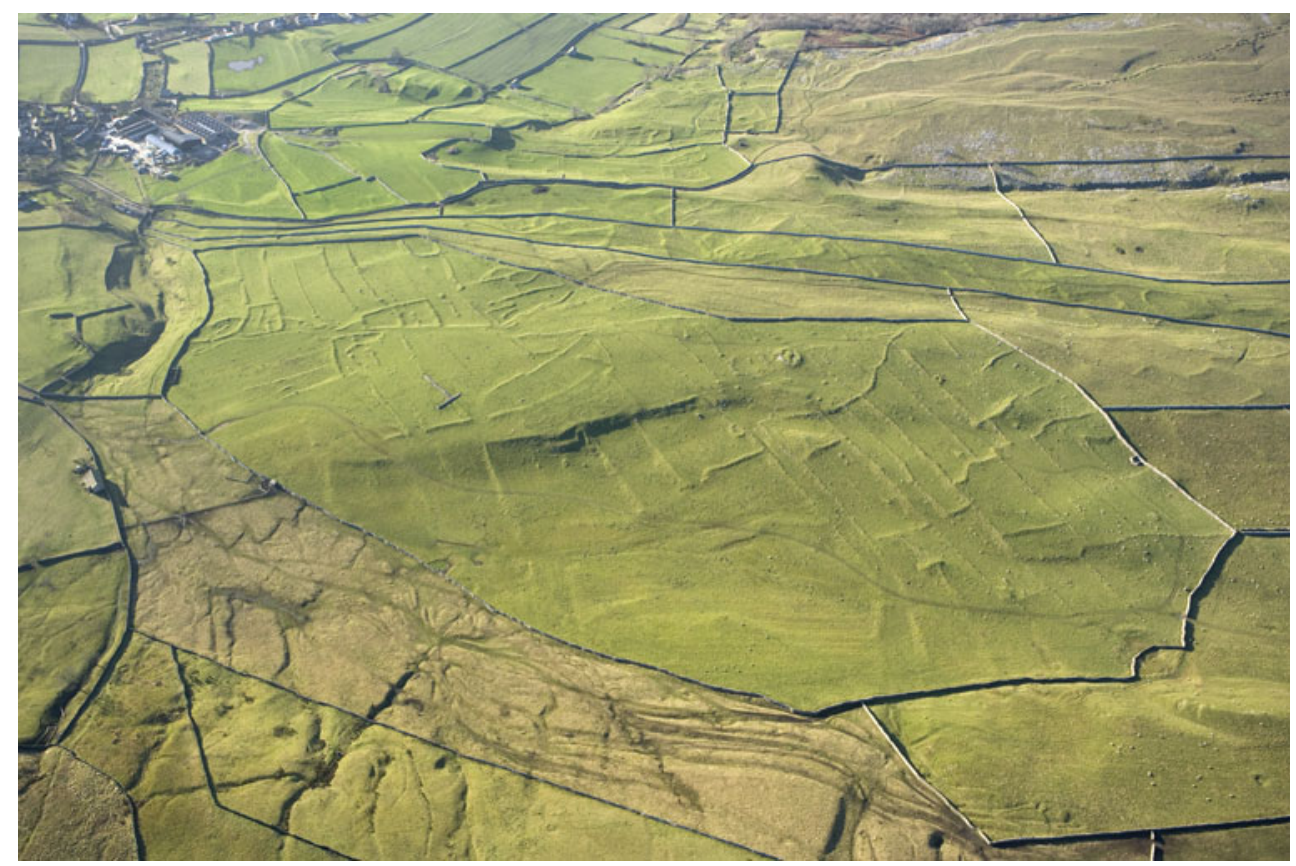

Figure 1. Earthworks of Iron Age/Romano-British field systems and enclosures at High Close, Grassington, North Yorkshire. The term coaxial fields refers to their adherence to a dominant alignment, often north-east to south-west, or north-south. The Grassington fields are associated with a range of other monuments including cairns, trackways, and enclosure compounds. (C) Historic England Archive, 20845_050 25-NOV-2008.

2013), while Philip Crocker's survey for Colt Hoare at Stockton, Wiltshire, identified Romano-British settlement overlying earlier field boundaries (Hoare, 1810: 39). In the early twentieth century, O.G.S. Crawford and the Curwens described the character of 'prehistoric' field systems (Crawford, 1923; Curwen \& Curwen, 1923), and Toms (1925) speculated that the field systems in Cranborne Chase, Dorset, dated to the Bronze Age or earlier. Around the same time, there was a growing interest in medieval field systems, especially open fields (Gray, 1915).

Subsequent archaeological work has refined our knowledge of the extent and character of land divisions of all ages (e.g. Bradley, 1977; Fleming, 1988; Yates, 2007; Oosthuizen, 2013; Rippon et al., 2015; Ten Harkel et al., 2017). Yet, despite their common occurrence and importance, the timing and tempo of their emergence and expansion is poorly understood. Attempts at synthesis between regions are hampered by the absence of robust scientific chronologies. For example, in southern England, Field (2008) suggested two major events of land division in later 'prehistory', while noting the need for an independent chronological framework. These are: the emergence of 'Celtic' and coaxial field systems in the mid-second millennium cal $\mathrm{BC}$, and the layout of larger, ranch-like land units in the first millennium cal BC.

The earliest examples of land divisions currently known in Britain date to the Early Bronze Age (e.g. Martin et al., 2012), while more appear later in the second millennium cal BC (e.g. Framework Archaeology, 2011). In some areas, the establishment of new field systems probably declined in the Iron Age (e.g. 
Lambrick \& Robinson, 2009: 80 ff; Sharples, 2010: 43) while different types of boundaries, such as linear earthworks and pit alignments, emerged (e.g. Bradley et al., 1994; Rylatt \& Bevan, 2007). Field systems were established in many areas in the Romano-British period (e.g. Garton et al., 2008) and had a variable impact on the shape of later, medieval landscapes (Rippon et al., 2015), which themselves evolved over time (e.g. Oosthuizen, 2013).

While the economic importance of field systems is obvious, they do more than enclose resources; they reflect aspects of social organization, including degrees of social stratification, control over people and animals, and ideas about ownership, belonging, and identity. Variation between regions may also suggest different trajectories of change; but the absence of independent chronologies severely limits our interpretations (see Løvschal, 2014).

Here, we address this lacuna by using the data acquired through development-led archaeology (some eighty per cent of scientific dates from sites in England), along with data from published sources, to produce the first robust chronology for land division features from a region of Britain. We have chosen Yorkshire and the northeast Midlands (Figure 2), areas with wellpreserved land divisions from various periods but with a specific regional character and historical trajectory that is distinct from better known parts of Britain such as southern England.

\section{The Study Region}

Evidence from across Yorkshire and the north-east Midlands shows a wealth of types of land divisions that are thought (on the basis of relative typo-chronologies) to date from the Bronze Age onwards. In the north-east Midlands, Bronze Age field systems have been identified in both upland and lowland contexts, for example in the Lower Welland valley in Lincolnshire and on the East Moors in Derbyshire (Willis, 2006: 94-5). By contrast, the main period of field system creation in Yorkshire appears to be the Iron Age, though linear earthwork land divisions on the Wolds were in use by the end of the second millennium cal $\mathrm{BC}$ (Manby et al., 2003; Mackey \& Manby, 2003). The so-called embanked 'Celtic field' systems, for example at Craven in North Yorkshire (King, 1985), have no satisfactory chronologies. They are often suggested to have been established in the Iron Age but could equally have resulted from Bronze Age activity (Manby et al., 2003: 103).

In some parts of the study area, the appearance of enclosed field systems seems to be a later development, spanning the Late Iron Age and Early Romano-British periods; this includes the distinctive "brickwork plan' coaxial systems found by aerial photography on the Sherwood Sandstones of northern Nottinghamshire and South Yorkshire (Willis, 2006: 113; Garton et al., 2008; Figure 3). Aerial mapping has also provided good, if fragmentary, information about the general layout and extent of field systems for the Iron Age and RomanoBritish periods of the Lincolnshire Wolds and the valleys of the Trent and Welland (Willis, 2006: 145). Field systems assumed to be of Iron Age or Romano-British date are also known in the Yorkshire Dales (Horne \& MacLeod, 1995).

Later 'prehistoric' linear ditch systems are numerous in parts of the study region, including south-west Lincolnshire, where a band of multiple-ditched linear boundaries cross the Jurassic Limestone Ridge (Willis, 2006: 123). However, there are relatively few Romano-British and postRoman earthworks within the north-east Midlands, the Grey Ditch in Derbyshire is the clearest example (Guilbert \& Taylor, 1992). The Yorkshire Wolds dyke systems appear to have had a long history of 


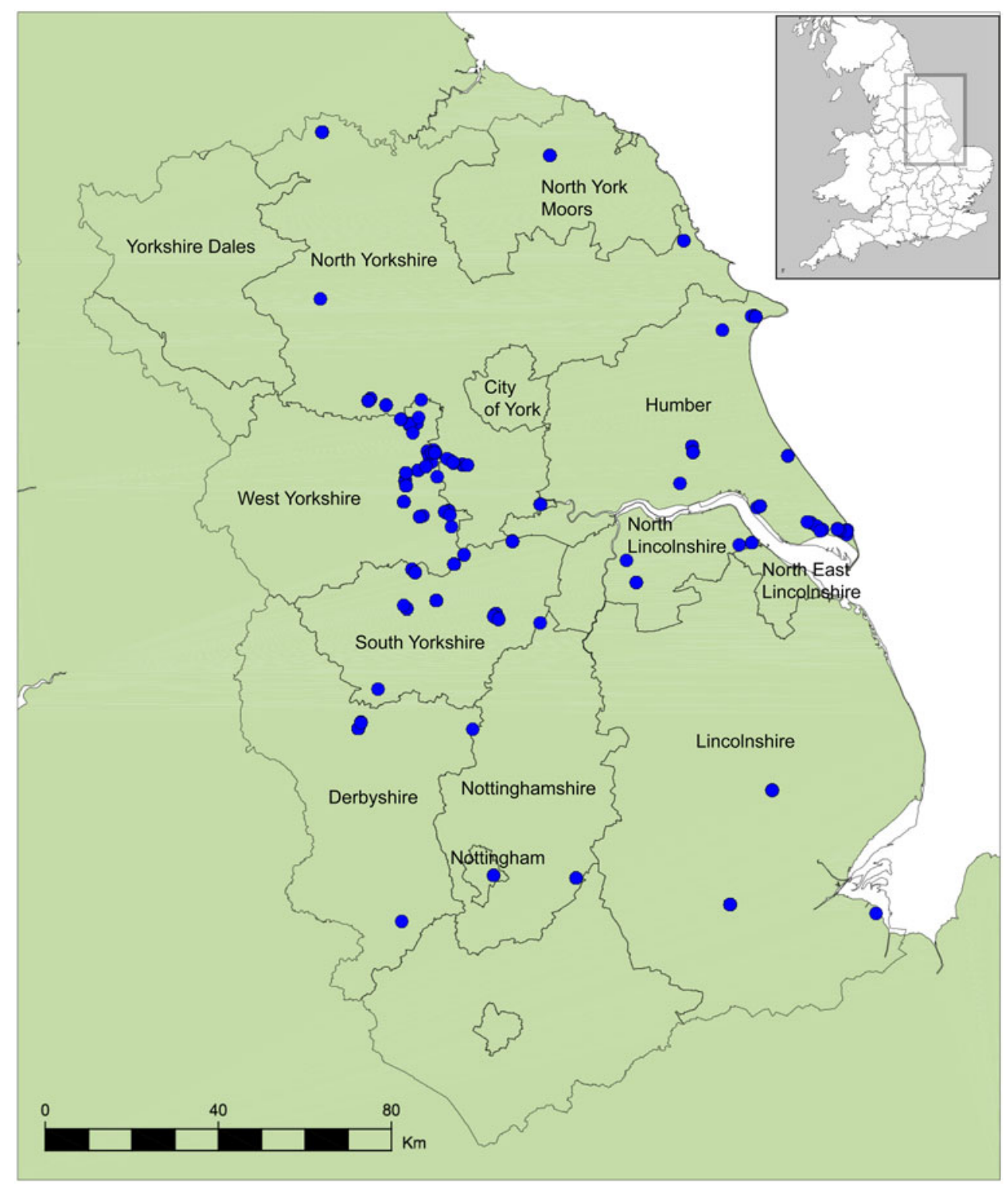

Figure 2. Historic Environment Record (England) regions included in this study, showing the locations of sites with scientific dates discussed.

development from the Late Bronze Age to the Late Iron Age or beyond (Dent, 1984; Giles, 2012), without major disruption to the landscape organisation. Pit alignments are also found on the Yorkshire Wolds as cropmarks; the associated banks survive in places on the North York Moors, for example on the Tabular Hills (Spratt,
1988). When these features are excavated, they usually appear to be associated with 'prehistoric' activity, though RomanoBritish examples are also known.

In the medieval period, most of the region was part of the 'Central Province' as defined by Roberts and Wrathmell (2002). This was a broad sweep of land 


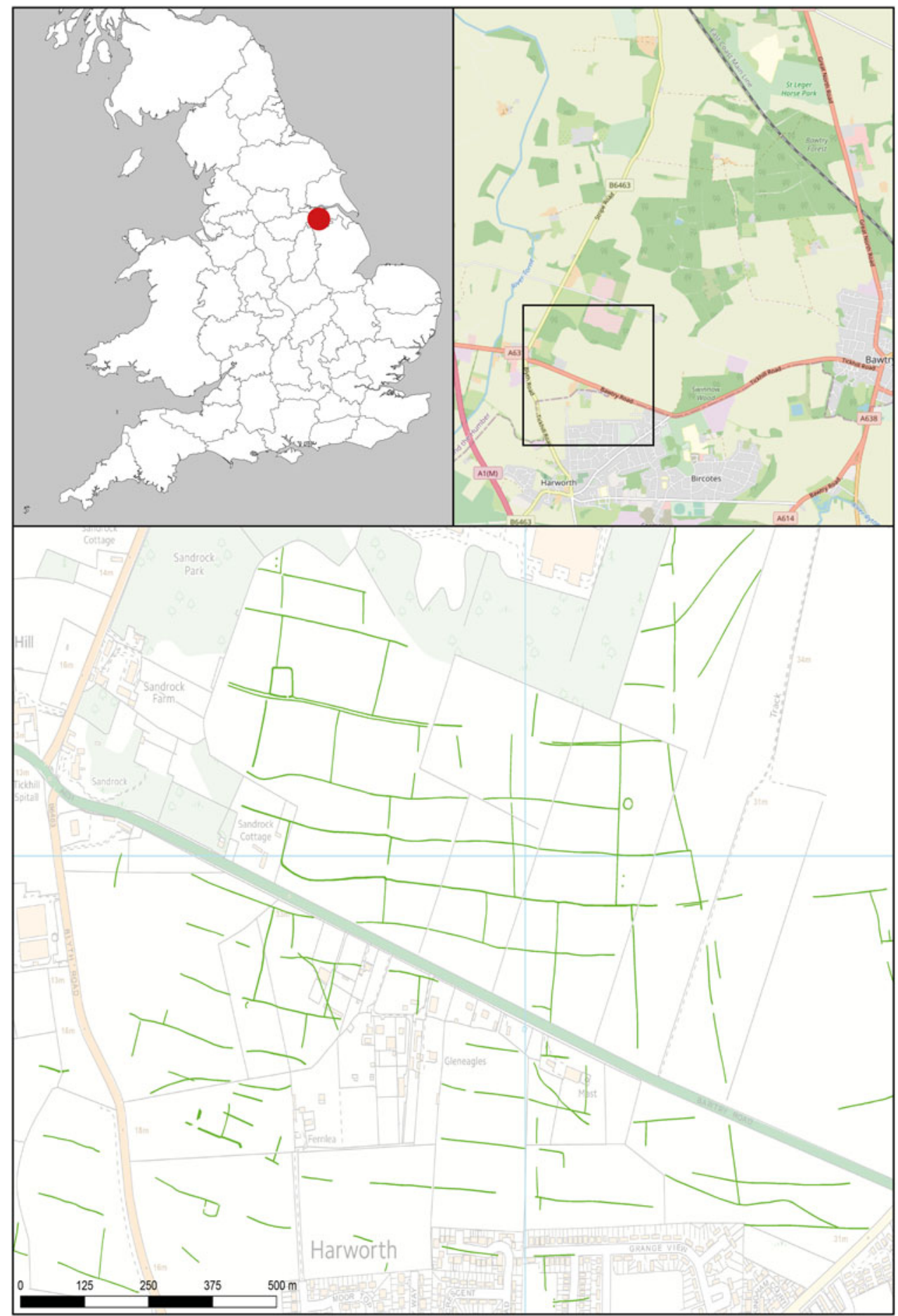

Figure 3. Cropmarks of Iron Age/Romano-British coaxial fields north of Harworth, South Yorkshire, and inset showing the general location of Harworth. Base map and data from OpenStreetMap and OpenStreetMap Foundation. Aerial mapping ( $)$ Historic England. Basemap (c Crown Copyright and database right 2021. All rights reserved. Ordnance Survey Licence number 100019088. 
extending from Dorset on the south coast to the north and east, encompassing the area east of the Pennines. Much of the landscape here is known as a 'champion landscape', with arable land organized into open fields divided into strips and cropped under a two- or three-year rotation. Once extensively covered with ridge-and-furrow, much of the medieval landscape has been destroyed by modern cultivation, though parts of the north-east Midlands retain wellpreserved areas of ridge-and-furrow field systems, including areas of Lincolnshire.

The field systems of 'non-champion' regions- such as the Lincolnshire fenland, northern and western Derbyshire, Nottinghamshire, and the Pennines-tend to be less regular and were organized in a variety of ways; these regions have generally been little studied (Lewis, 2006: 207). An exception is the Yorkshire Dales, where the well-preserved field systems associated with medieval townships have revealed many phases of development from the seventh to the seventeenth century AD (Moorhouse, 2003).

\section{Project Approach}

Our aim was to examine changes in practices of land division across traditional culture historical divisions in this region, in particular changes in the scale and rate of land division over the very long term. We were interested in what a study at this scale might indicate in terms of the social contexts in which these changes took place. We collected scientific dating evidence associated with a wide range of land division types: aggregated field systems, coaxial field systems, enclosures, settlement enclosures, stock enclosures, field boundaries, boundary ditches, ditches, dykes, pit alignments, linear earthworks, and trackways or droveways (Figures 1 and 3; Supplementary Material Figures S2-S10 and Supplementary Material Table S1 for land division definitions). Several of these feature types are not classic 'field systems', but we selected a broad sample to examine land division in the widest sense.

Building robust chronologies for land division presents several distinct challenges. The first hurdle is semantic: when does a 'ditch' become a 'field boundary' (see Chadwick, 2008), especially when identified in a narrow evaluation trench? For this study we chose to rely on the terminologies used in the excavation reports.

Establishing a robust scientific chronology for land division is by no means straightforward. Samples for radiocarbon dating from land divisions rarely come from clearly understood 'archaeological events of interest', and infrequently represent in situ activities, Gwithian in Cornwall is one of a few known exceptions in Britain (Nowakowski, 2009). We can think about the archaeological event of interest' as some form of distinct anthropogenic activity. It could be, for example, the point in time when a field system is first excavated, or the system deconstructed. However, any samples for radiocarbon measurements from this feature may not be well-associated with the excavation of the field system (see discussion below). Land divisions are often negative features in which materials suitable for radiocarbon measurement can accumulate. However, this accumulation can result from a variety of complex processes (for example, manuring using midden deposits), and features may fill and be recut over long periods (Johnston, 2005). Samples from such features have the potential to be residual. For example, the Bronze Age field systems at Fengate, Peterborough, Cambridgeshire, were originally dated to the Late Neolithic because their fills contained Grooved Ware pottery. The pottery had been redeposited in the field ditches when their digging disturbed earlier features (Evans, 2009). 
Producing robust estimates for the establishment of land divisions is, therefore, challenging. In many cases, while ecofacts from within land divisions may not directly relate to the establishment or decommissioning of a boundary, such material may provide estimates for a boundary's active use in a landscape.

In the examples identified in our study, there are no chronometrically dated samples that have a clear functional relationship (Waterbolk, 1971) with the establishment of these features. This may partly be due to the underlying geology of parts of our study area, which affects bone preservation in some cases. It may also reflect past activities associated with land division, as opposed to the more frequent occurrence of placed deposits in more obviously 'monumental' structures or settlements.

To address these issues, we applied two analytical approaches: one uses site-specific Bayesian analysis of scientific dates, and then 'currency models' to explore the timing and tempo of types of land division (see Supplementary Material for discussion). The other looks at long-term patterns in the scale and frequency of all forms of land division over some 3000 years. Our approach was designed to look in a granular fashion at the temporal 'currency' of different types of land division, but also to shift perspective and examine the long-term trends in all the evidence available. This dual approach makes it possible to think about complex and difficult datasets in different ways.

\section{Methods}

The data collection methods, modelling choices, and results are comprehensively discussed in the Supplementary Material, which also provides full references for the individual sites and every chronometric measurement used in our analysis. The reporting follows criteria outlined in Bayliss (2015). As with any 'legacy data' project, there are strengths and challenges when dealing with such an inheritance.

Bayesian chronological modelling was undertaken using the program $\mathrm{OxCal}$ v4.3 (Bronk Ramsey, 2009) and the calibration dataset of Reimer et al. (2013). The chronological models for each site are described (see Supplementary Material) and defined exactly in the figures and the OxCal code (Supplementary Material). In the text and tables, the Highest Posterior Density intervals of the posterior density estimates are given in italics, followed by a reference to the relevant parameter name and the figure in which the estimate is defined. Our other approach to long-term trends is afforded by Kernel Density Estimation (KDE; Bronk Ramsey, 2017), a widely used non-parametric method for estimating underlying distributions of discrete data points (here, dated samples). The number of samples selected for radiocarbon measurements will affect these KDE distributions; for example, if fewer measurements were commissioned from boundaries containing Romano-British material culture, this part of the $\mathrm{KDE}$ plot will be lower. This analysis does, however, allow us to take the long view of the available evidence for land division as a whole across different feature 'types', and traditional culture historic or period divisions.

\section{Results}

The number of active likelihoods (radiocarbon dates and posterior density estimates) and sites represented in the currency models for each type of land division is shown in Figure 4. By far the most frequent feature type from which chronometric measurements are produced are discrete enclosures; this may reflect their relative frequency over time, but also 


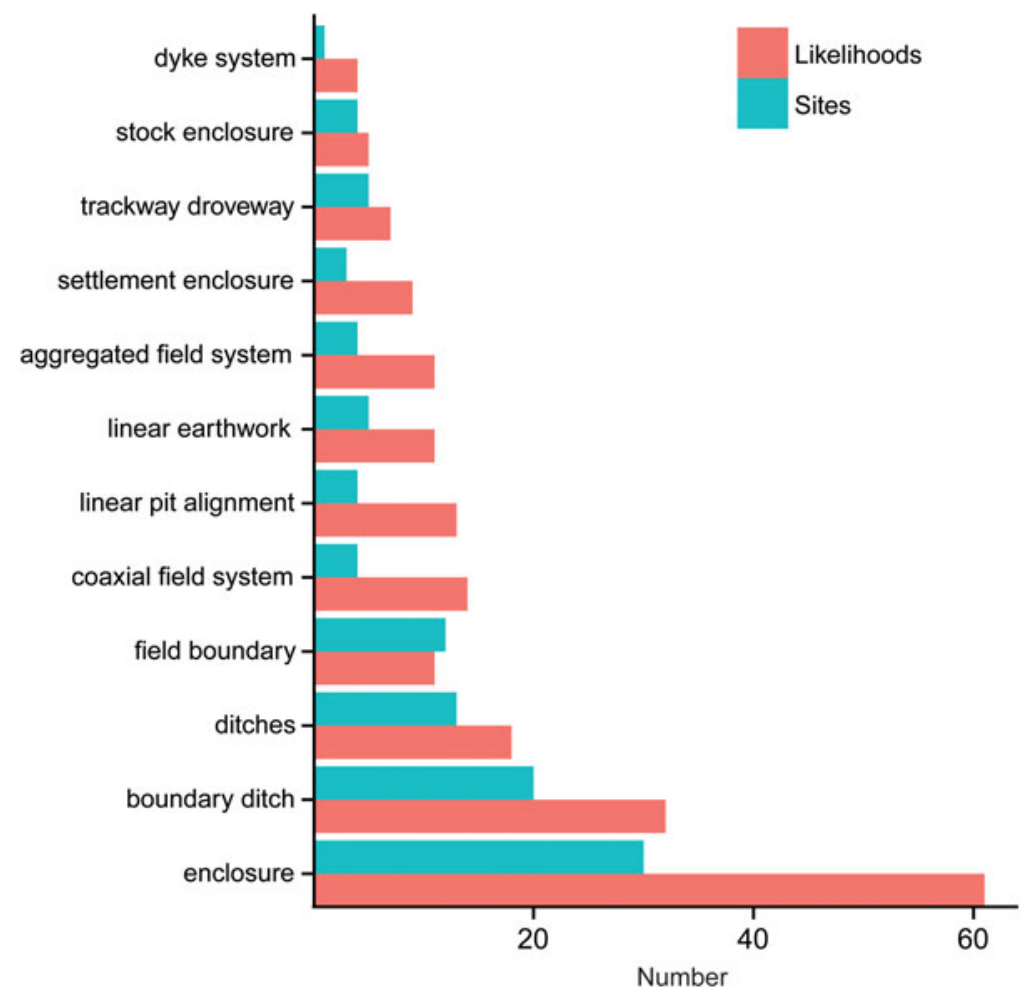

Figure 4. The number of active likelihoods used in the currency model for different types of feature (in red), and the number of sites with active likelihoods (in blue).

that they are more likely to be positively identified as 'sites' and subject to more chronometric measurements than simple linear features.

Figure 5 shows a summary of the model for land division (see Supplementary Material) and a timetable for the appearance of different feature types. Overall, land division began in 1815-1490 cal $B C$ (95\% probability; Start_Start_Dividing_ the_Land; Figure 5), but the timescale of the beginnings of land division was very drawn out, spanning 785-1280 years (95\% probability; distribution not shown). In our region, there was a very slow uptake in practices of enclosing and dividing the land. Key estimates for the beginning of use for each class of land division are summarized in Table 1 and Figure 6. Aggregated field systems were the first class of land division to appear in the second quarter of the second millennium cal BC, followed by features identified by excavators as individual ditches (which could, of course, be parts of field systems) and then enclosures (discrete features not part of a field system).

After c. $800 \mathrm{cal} B C$, there is a marked change in the tempo and variety of land division, with the first appearance of a much wider range of types of land division between 800-400 cal BC. These include stock enclosures (770-505 cal BC; 95\% probability; first_stock_enclosure; Figure S97), trackways (780-470 cal BC; 95\% probability; first_trackway; Figure S94), boundary ditches (725-690 cal BC; 2\% probability; or 665-305 cal BC; 93\% probability; first_boundary_ditch; Figure S92), and linear earthworks (670-410 cal BC; 95\% probability; first_linear_earthwork; Figure S104; Supplementary Material: Table 1). 


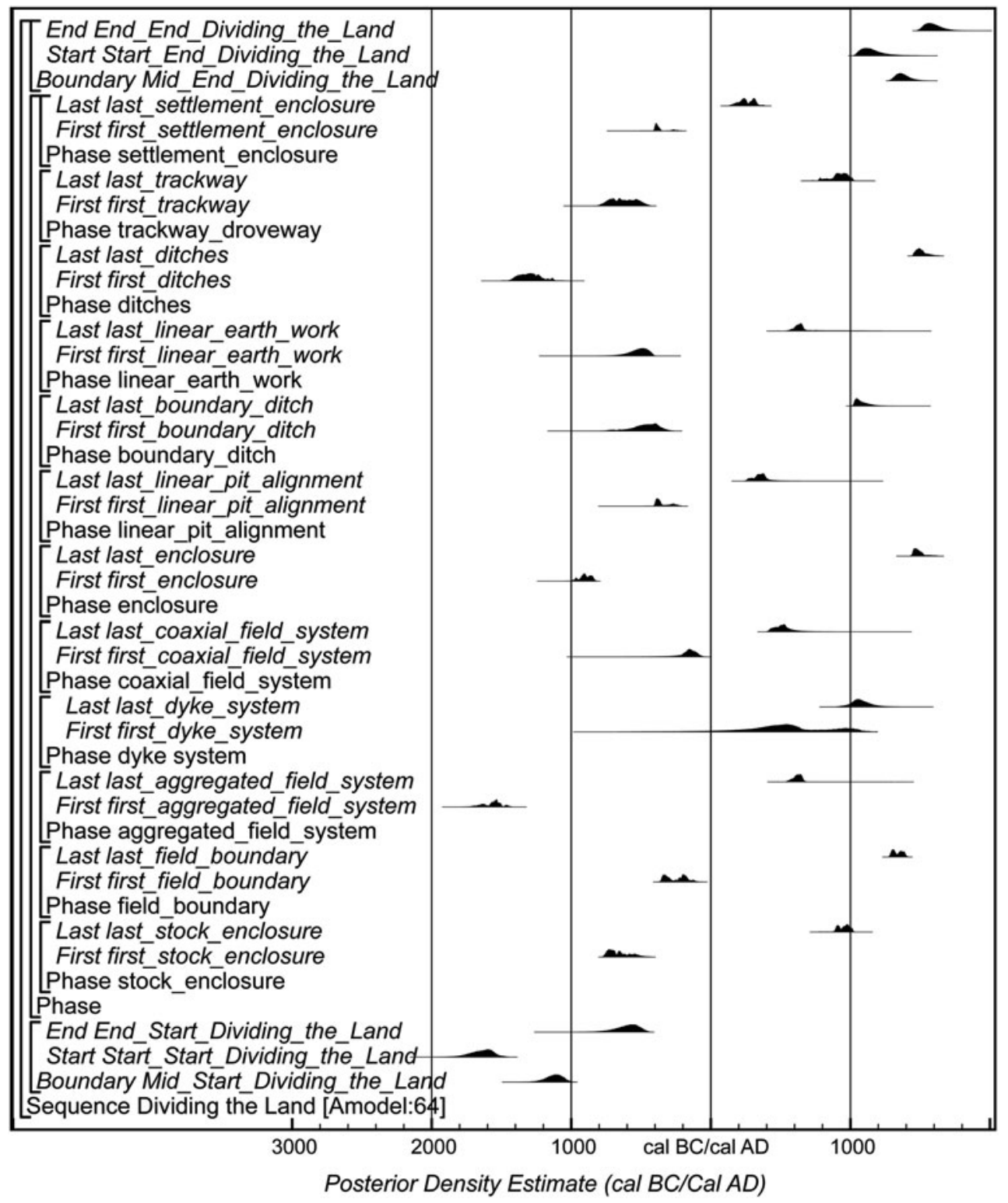

Figure 5. Overall structure of the chronological currency model for all the data analysed as part of 'Dividing the Land' project calculated using trapezium boundary parameters (Lee E Bronk Ramsey, 2012). The component sections of this model are shown in detail in Supplementary Material, Figures S88-S105. The distributions shown here are posterior density estimates produced through the Bayesian analysis. The large square brackets on the left-hand side of the figures, along with the OxCal keywords, define the model exactly, as does the code in the Supplementary Material.

Further types of land division begin to appear most probably after $400 \mathrm{cal}$ BC, including the first appearance of linear pit alignments (410-230 cal BC; 95\% probability; first_linear_pit_alignment, Figure S103), field boundaries (360- 115 cal BC; 95\% probability; first_field_boundary; Figure S88), coaxial field systems (365-50 cal BC; 95\% probability; 
Table 1. Highest Posterior Density intervals for the currency of different classes of land division in Yorkshire and the north-east Midlands, calculated by the currency model shown in Figure 5 and Supplementary Material Figures S88-S105.

Parameter name (Figure 5)

Start_Start_Dividing_the_Land

Mid_Start_Dividing_the_Land

End_Start_Dividing_the_Land

Duration_Start_Dividing_the_Land

Start_End_Dividing_the_Land

Mid_End_Dividing_the_Land

End_End_Dividing_the_Land

Duration_End_Dividing_the_Land

first_aggregated_field_system

last_aggregated_field_system

first_ditches

last_ditches

first_enclosure

last_enclosure

first_stock_enclosure

last_stock_enclosure

first_trackway

last_trackway

first_boundary_ditch

last_boundary_ditch

first_linear_earth_work

last_linear_earth_work

first_linear_pit_alignment

last_linear_pit_alignment

first_field_boundary

last_field_boundary

first_coaxial_field_system

last_coaxial_field_system

first_settlement_enclosure

last_settlement_enclosure

first_dyke_system (renamed from 'start_Danby_Rigg' in Supplementary Material)

last_dyke_system (renamed from 'end_Danby_Rigg' in Supplementary Material)
Highest Posterior Density interval (95\%

probability unless otherwise stated)

$$
\begin{aligned}
& 1815-1490 \mathrm{cal} B C \\
& 1250-1010 \mathrm{cal} B C \\
& 785-450 \mathrm{cal} B C \\
& 795-1280 \text { years } \\
& \text { cal } A D 1030-1340 \\
& \text { cal } A D 1285-1480 \\
& \text { cal } A D 1490-1715 \\
& 200-650 \text { years }
\end{aligned}
$$

1715-1490 cal BC (88\% probability) or 1485-1440 cal BC (7\% probability)

cal AD 545-675

1435-1125 cal BC

cal $A D$ 1445-1590

980-830 cal BC

cal $A D$ 1435-1590

770-505 cal BC

cal $A D$ 890-1020

$780-470 \mathrm{cal} B C$

cal $A D 775-1020$

725-690 cal BC (2\% probability), or 665-305 cal BC (93\% probability)

cal AD 1010-1215

$670-410 \mathrm{cal} B C$

cal $A D$ 540-1040

410-230 cal BC

cal AD 250-480

360-115 cal BC

cal $A D$ 1285-1400

$365-50 \mathrm{cal} \mathrm{BC}$

cal $A D$ 405-710

$415-350$ cal BC (81\% probability) or 290-230 cal BC (14\% probability)

cal AD 145-345

cal $A D$ 100-1110

cal AD 930-1230 


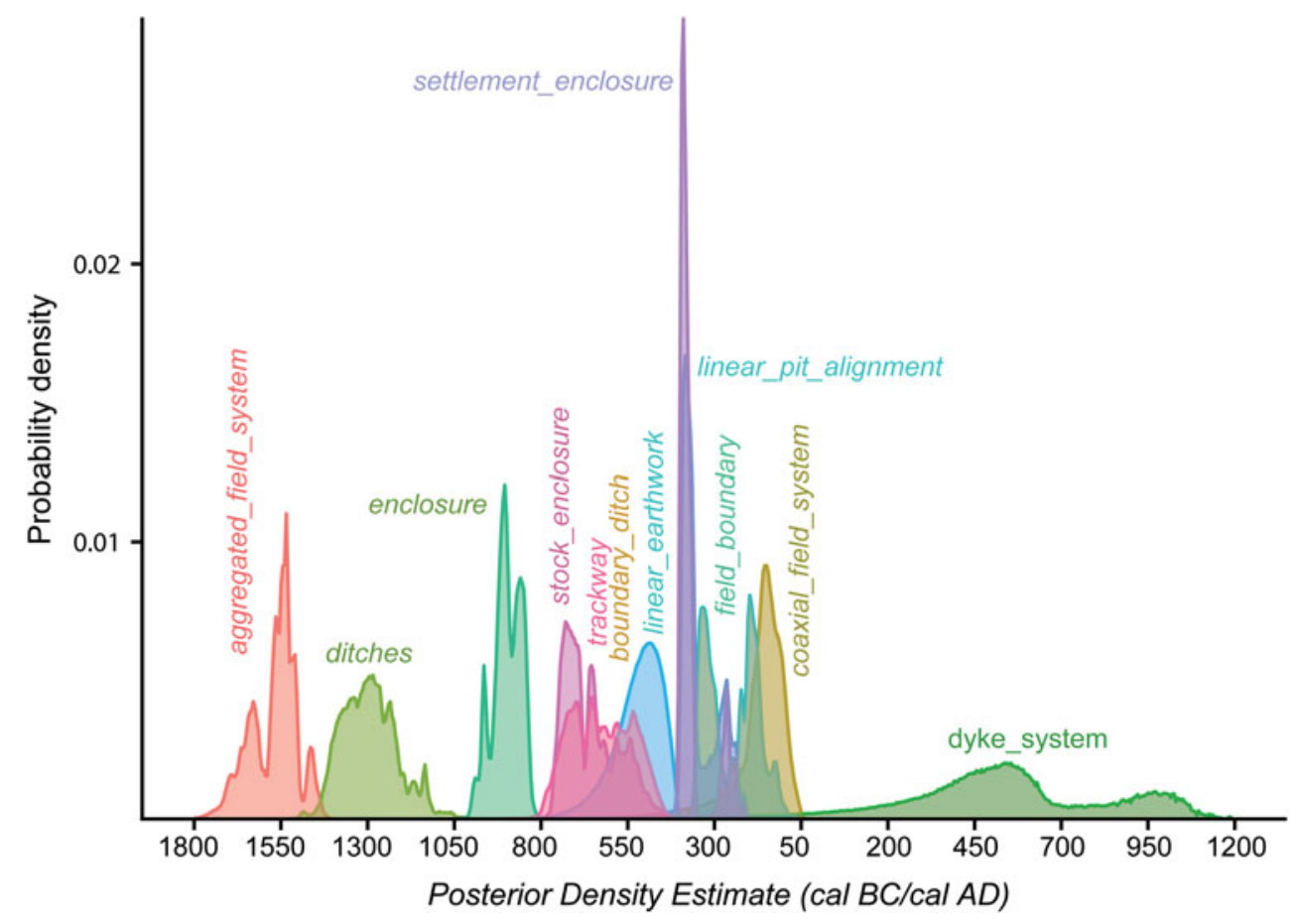

Figure 6. Probability distributions of dates for the start of land divisions (some of the tails of these distributions have been truncated to enable detailed examination of the highest areas of probability), derived from the model shown in Figure 5.

first_coaxial_field_system; Figure S90), and settlement enclosures (415-350 cal BC; 81\% probability or 290-230 cal BC 14\% probability; first_settlement_enclosure; Figure S100).

\section{The Use of Land Divisions}

Figure 7 provides a long-term, landscapescale impression of the intensity of change across the whole study region. Different types of land division had relatively long periods of use. This may derive in part from issues of taphonomy of the dated samples, and from histories of reuse, which may be important indications of related social practices (see below).

Four 'big trends' of archaeological interest are highlighted by the $\mathrm{KDE}$ plot. First, there was a very low level of land division until c. $700 \mathrm{cal} \mathrm{BC}$. This suggests that, in contrast to areas in southern Britain, Bronze Age fields were sparsely distributed across the region. This pattern appears to be real for three reasons.

We would expect negative features used for Bronze Age land division to be identified through excavation, if they existed, since later features on the same underlying geology are being found by excavation in the region. Secondly, the regional Bronze Age ceramic chronology is not so precisely dated that researchers would dismiss the opportunity to obtain radiocarbon measurements (see discussion of Romano-British material below). Finally, given that there is other evidence of Bronze Age activity in the region (e.g. Clay, 2006: 82-3; Richardson, 2011), this trend does not reflect a general absence of Bronze Age activity in the region.

A second 'big trend' occurs from c. 700 cal $B C$. A rapid increase in dated samples 


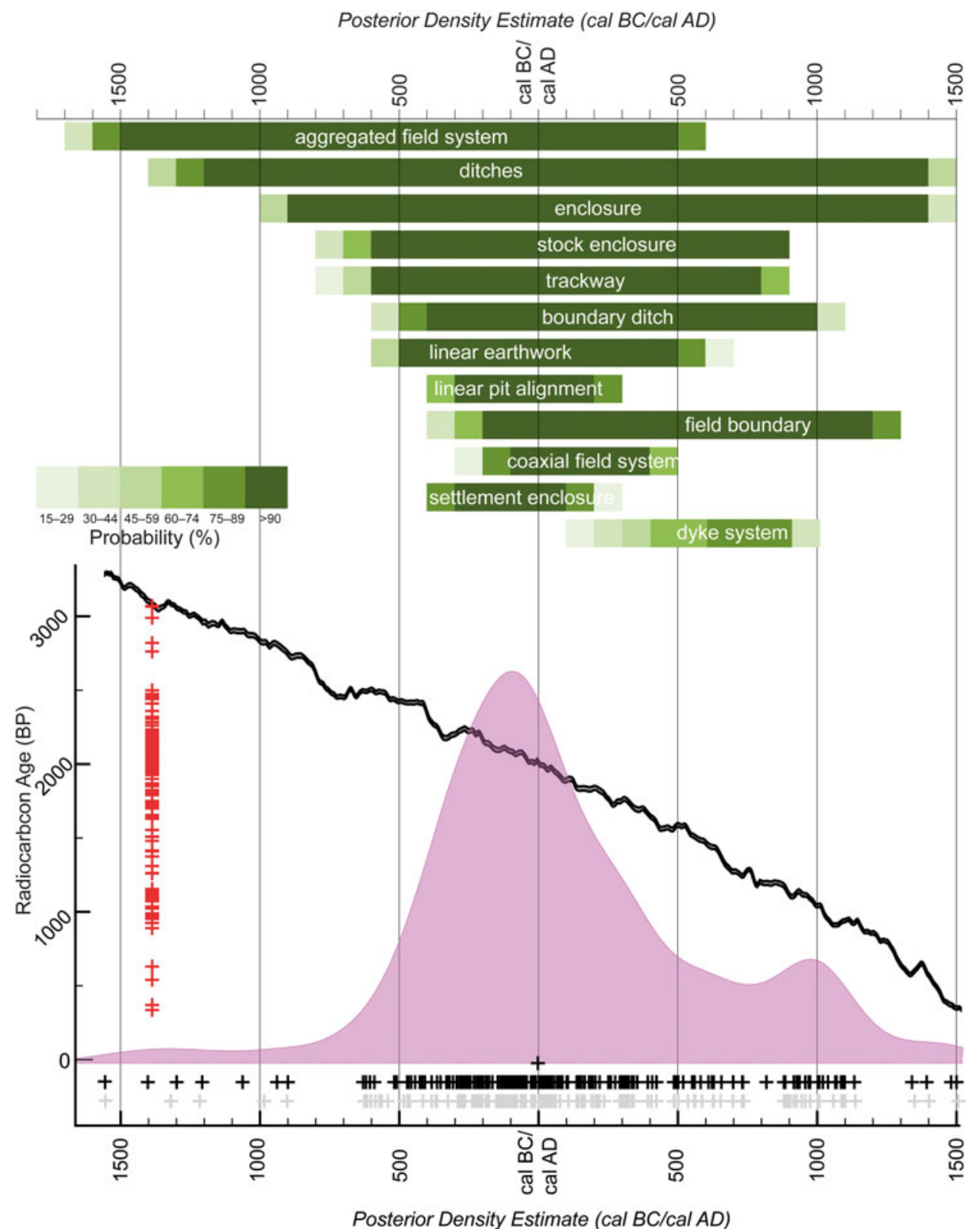

Figure 7. Top: schematic diagram showing the use of land divisions in Yorkshire and the north-east Midlands; horizontal bars represent the probability that a land division type was in use in each 100year period (darker shading indicates higher probability). Bottom: Kernel Density Estimate for the plot of the overall distribution of posteriors associated with land division in the study area. The estimate is calculated for the whole dataset in the model shown in Figure 6. The black crosses represent the medians of the posteriors, with the medians of the calibrated results in grey. The medians indicate the distribution of results over time. The red crosses are uncalibrated medians of radiocarbon results. The Kernel Density Estimate is plotted against the calibration curve, which is shown in black. 
peaks in the first century cal $\mathrm{BC}$, to gradually fall until c. cal $A D$ 800. We suggest that this represents significant increases in land division from the earlier part of the Iron Age onwards, with the greatest intensity around $1 B C / A D$. In terms of types of land division, enclosures, trackways, and linear earthworks mark the earlier part of the Iron Age, with new types of land division and increasing numbers of field systems documented in the later Iron Age and Romano-British periods.

A third trend consists of a further small rise in land division, peaking at c. cal $A D$ 1000, which appears to correlate with the creation of villages and open fields in the Central Province (as defined by Roberts \& Wrathmell, 2002). This is generally assigned to the period from the eighth to tenth centuries AD (Rippon et al., 2015: 97-9, 329-31). The 'Harrying of the North' between AD 1069-70 (i.e. the campaigns to suppress northern England after the Norman conquest) has also been suggested to have resulted in the large-scale reorganization of landscapes across northern England, with villages established or rebuilt, and monastic estates founded (Hadley, 2000: 173), though others have suggested that the changes in settlement form reflect longer-term trends (Creighton \& Rippon, 2017: 76-7). The peak in our analysis appears to occur slightly earlier than the conquest - in the tenth and eleventh centuries cal AD. This suggests that enclosure in these centuries was part of a much lengthier pattern of change, underway before the Norman conquest. This would seem to be closer to the date range often suggested for the nucleation of settlement across the Central Province, and closer to the period of Scandinavian settlement and political control in this part of England under the Danelaw (i.e. northern, central, and eastern parts of early medieval England originally colonized by the Danes where a form of law that differed from West Saxon and Mercian laws prevailed).
A final important observation emerges from comparing the output of our two analytical approaches (Figure 7) with respect to the magnitude of these long-term changes. By comparing the trend after $c .700 \mathrm{cal} \mathrm{BC}$ and that around cal $A D 1000$ with the shape of the calibration curve, we can be confident that the trends are real, since they are independent of the calibration dataset.

The division of the land after $c .700 \mathrm{cal}$ $B C$ is of a much greater magnitude than that documented in any other period. There was a significant change in both the frequency and scale of land division in the last quarter of the first millennium cal $\mathrm{BC}$ : people became more active in dividing the land over the course of the Iron Age and employed new ways of doing this. This appears to have started with individual enclosures and land divisions perhaps associated with routeways and large-scale divisions across the landscape, to a gradual increase in emphasis on parcelling up the land over the Iron Age.

\section{Discussion: TimescaPes}

The approach we have taken here can be classed as a 'timescape'. This way of proceeding combines different analytical approaches to evidence for change across traditional culture historical divisions (Griffiths, 2017). In this case, we have constructed robust, formal chronologies at a broad scale across these traditional culture historic divisions.

While not suggesting that the significant trends we have identified reflect the same concerns in all periods, we can say that the increased and intensive demarcation of space at given times suggests profound social change in terms of regulation of movement, access to land, and a heightened interest in demonstrating social inequalities, perhaps underscored by changing notions of land tenure and 'ownership'. 
The signal we have identified in Yorkshire and the northern Midlands over the Iron Age is most striking, and suggests an increasing emphasis on social hierarchy and identity. We may be able to see this in the limited number of prominent enclosed settlements such as Stanwick (Haselgrove, 2017). Notably, in the Arras burials of the Yorkshire Wolds (late fifth to early first century $\mathrm{BC}$ ), we see a society interested in the production and display of identity and status (Giles, 2012; Jay et al., 2012: 181). Outside our study areas, other evidence of social changes at this time include: the reorganization of the landscape in regions such as Wessex, which has been the focus of more research (Cunliffe, 2004); growing numbers of enclosed settlements that may indicate heightened social and 'functional' differentiation and, perhaps, instability (Thomas, 1997); and an increase in votive deposits and metalwork hoards (Bradley, 1990).

Our evidence suggests that societies in our region might have seen the beginnings of social differentiation several hundred years before the Late Iron Age floruit. From c. $700 \mathrm{cal} \mathrm{BC}$ onwards, patterns that are consistent with an increasing concern for regulating access to land and demonstrating associations with land emerge, perhaps to express individual and group identity and status, and, increasingly, as a form of social capital. This emphasis on land division, and the social processes it indicates, may not have taken place as early as in southern England, but it was well before the emphasis on differentiation and identity evident in the later Iron Age Arras burials, for example. We suggest that these later Iron Age processes of creating identities, social differentiation and these later patterns of inequality therefore may have much earlier roots, beginning with changes apparent in the rate of land division from $c .700 \mathrm{cal} \mathrm{BC}$ onwards. These land divisions may represent changing agricultural practices; however, direct comparative dating studies on the frequency of domesticates from across the study region (as well as other evidence for agricultural practices) would be needed to establish this independently. In a region where increasing evidence for interest in defining social identity in the later Iron Age is evident, these features can be seen as media through which people created markers of tenure, inheritance, and relatedness (Giles, 2007).

These social changes are emphasized by the changes in frequency and form of land demarcation over the Iron Age; this is not 'simply' an increase in the appearance of nucleated villages and open fields. Such frequency is unlikely to be an effect of the shape of the calibration curve or sample bias; those archaeologists researching the second half of the first millennium cal $\mathrm{BC}$ are often disinclined to obtain radiocarbon measurements because of a perception that the shape of the calibration curve will not be precise enough to address their research questions (Hamilton et al., 2015). That we still identify this signal at a time when researchers might be less likely to submit radiocarbon samples-if they suspected material to be 'Iron Age'-emphasizes the significance of this pattern. Moreover, our approach, emphasizes the scale of this change in organization of the landscape compared to what went on at other times.

The peak in evidence for land division in the second half of the first millennium $\mathrm{cal} \mathrm{BC}$ is unlike that observed in any other period in Yorkshire and the north-east Midlands; the transformation was substantially different in nature from any earlier type of land division. This landscape reorganization was perhaps the most significant and profound reordering of space witnessed in the British countryside until the forced enclosures under the Acts of Parliament from the eighteenth century $\mathrm{AD}$ onwards (Wordie, 1983). Certainly, 
the changes that occurred over the first millennium cal BC were of a substantially different nature than any type of land division that had occurred before.

Switching between scales also allows critical consideration of regional trends in landscape development. Our region lacks the extensive rectilinear field systems that were widespread in southern Britain during the second millennium cal $\mathrm{BC}$ (Yates, 2007). The earliest land divisions in Yorkshire and the north-east Midlands begin with localized aggregated enclosures, more characteristic of western and northern Britain. Our region's large-scale lowland field systems have a distinct identity within the landscapes of enclosure of the first millennium cal BC in northwestern Europe (Løvschal, 2020), though this pattern may also reflect the focus of development-led work on lower-lying landscapes.

The decline in the signal for land division in the Romano-British period may be due to several factors. A continuity of land divisions established in the first millennium cal $\mathrm{BC}$ may have played a part, as could a dearth of radiocarbon results obtained for samples from RomanoBritish features, for which typo-chronological dating is often more precise than for the preceding periods. Alternatively, the types of land division used in Romano-British societies could have relied less on substantial negative features, with boundaries defined by lighter fencing or hedging, for example.

Continuities in landscape organization into the early post-Roman period have been suggested at individual sites (e.g. Vervust, 2020), while Rippon et al. (2015) concluded that sixty-four per cent of excavated late Romano-British fields in lowland England and Wales (and seventy per cent in their Central Zone) had shared alignments with medieval field systems (see also Oosthuizen, 2013). By contrast,
Chadwick (2010: 444) argued for a discontinuity between Romano-British and medieval fields across the lowlands of our study region. Our own approach shifts the emphasis towards the reasons why the timing of land division was so variable across different regions, and especially how the rate of change varied.

We have identified a number of themes that could be addressed by future research. First, we need more robust data. The existing corpus of scientific dates for different types of land division (Figure 5) highlights a situation that can only be improved through chronologies for individual sites. In our study area, and north-western Europe generally, it is development-led archaeology that is leading this work. Marked variations in the intensities of land division through time have been identified, but finer resolution for our histories may be hindered by the plethora of terms used to describe categories of land division. This is an expression of a wider problem. For example, terms such as 'Celtic fields' refer to quite different land divisions in across north-western Europe (e.g. Whitfield, 2017, Neilsen et al. 2018).

Second, we need to revisit our approaches to writing histories. While site-specific Bayesian models can radically alter our understanding of a sequence of change, we need to use different analytical lenses to think about the structure of our narratives and how we write about change (Griffiths, 2017). The land divisions of the second and first millennia cal $\mathrm{BC}$ are a north-western European phenomenon (Løvschal, 2020), and the ability to integrate British and European Iron Age evidence has been a subject of significant debate (Hamilton et al., 2015). One cause of tension is that explanations of the links between Iron Age European communities are still led by material culture studies (e.g. Garrow et al., 2009), although scientific dating has demonstrated that these models 
can be extremely misleading (Jay et al., 2012).

Here, we have focused on exploring a region over the very long term, using a variety of analytical approaches to shift our interpretative lenses. The trends we have identified contrast with the picture for southern England, but they also show similarities and differences with areas further afield. There is clear potential for future research on an even broader scale. We need chronometric data and a range of analytical approaches to write histories that use chronological (rather than typological or culture historic) frameworks to structure our narratives of social change at a transnational scale.

\section{Conclusions}

While several overviews of land division in Britain and northern Europe have been produced recently (e.g. Chadwick, 2010; Ten Harkel et al., 2017; Løvschal, 2020), this study represents the first attempt at producing a long-term, geographically wide-ranging, robust chronology for the timing and tempo of land divisions that transcend traditional period boundaries for a region of the British Isles. It identified evidence for the origin of land divisions in Yorkshire and the north-east Midlands in the mid-second millennium cal BC, followed by an escalation after c. $700 \mathrm{cal} B C$ and, again, a peak around $c a l A D 1000$.

The taphonomy and associations of many of the dated samples in this study fall well-short of ideal sample selection criteria (Whittle et al., 2011: 38-40). Additional measurements from samples with well-defined taphonomies must be obtained. Where only material of uncertain taphonomy is available (e.g. disarticulated animal bones), multiple measurements on several types of materials or different species are required from the same context to assess chronological robustness. These samples should comprise single entity, 'short life' samples, with radiocarbon reservoirs that are clearly understood.

To work effectively with 'difficult' legacy data, we have developed an approach that analyses site-specific models of results with well-understood 'logical scaffolding' (Chapman \& Wylie, 2016) on the one hand, and $\mathrm{KDE}$ summaries on the other. Working from the site-specific, to currency models, to the regional longue durée provides complementary means to reassess such 'difficult' datasets. Furthermore, cutting across culture historical divisions offers a new perspective, allowing us to consider the relative scale of the radical changes in land organisation over the course of the Iron Age and after the Norman conquest in the context of a much longer trajectory of transformation. Analysing a specific type of land division, or class of monument, or 'package' defined by culturehistorical parameters would not be sufficient to achieve this kind of long-term perspective.

Our approach has emphasized the significance of the scale of changes that affected the landscape after c. $700 \mathrm{cal} \mathrm{BC}$, which would not have been apparent had we worked in a more traditional manner. The strength of this signal indicates a society where ideas about identity, status, and control of resources were being played out on the landscape in new ways, which dramatically escalated over several centuries, and which ultimately may have led to the social differentiation apparent in the first century cal BC. It is only by combining analytical approaches and taking the long view of land division that we begin to recognize quite how significant these changes were.

\section{Supplementary Material}

To view supplementary material for this article, please visit https://doi.org/10.1017/ eaa.2021.48. 


\section{ACKNowledgements}

This work was supported by Historic England under Grant 7710. We would like to thank all the Historic Environment Record Officers, archaeologists, and researchers who allowed us to collect data and generously responded to our queries. We have thanked these hard-working people in the Supplementary Material, as there are so many; we hope they understand! If we have forgotten anyone we apologize. We would like to thank our reviewers for their attention and helpful suggestions. We also thank the editor for her patience during our Covid-19-delayed resubmission.

\section{REFERENCES}

Bayliss, A. 2015. Quality in Bayesian Chronological Models in Archaeology. World Archaeology, 47: 677-700. https:// doi.org/10.1080/00438243.2015.1067640

Bradley, R. 1977. Prehistoric Field Systems in Britain and North-West Europe: A Review of Some Recent Work. World Archaeology, 9: 265-80. https://doi.org/10. 1080/00438243.1973.9979703

Bradley, R. 1990. The Passage of Arms: An Archaeological Study of Prebistoric Hoards and Votive Deposits. Cambridge: Cambridge University Press.

Bradley, R., Entwistle, R. \& Raymond, F. 1994. Prehistoric Land Divisions on Salisbury Plain: The Work of the Wessex Linear Ditches Project. Swindon: English Heritage.

Bronk Ramsey, C. 2009. Bayesian Analysis of Radiocarbon Dates. Radiocarbon, 51: 337-60. https://doi.org/10.1017/S0033822200033865

Bronk Ramsey, C. 2017. Methods for Summarizing Radiocarbon Datasets. Radiocarbon, 59: 1809-33. https://doi.org/ 10.1017/RDC.2017.108

Chadwick, A, 2008. Fields for Discourse? Towards More Self-Critical, Theoretical and Interpretative Approaches to the Archaeology of Field Systems and Land Allotment. In: A. Chadwick, ed. Recent
Approaches to the Archaeology of Land Allotment (British Archaeological Reports International Series 1875). Oxford: Archaeopress, pp. 205-37.

Chadwick, A. 2010. Fields for Discourse: Landscape and Materialities of Being in South and West Yorkshire and Nottinghamshire during the Iron Age and Romano-British Periods. A Study of People and Place (unpublished $\mathrm{PhD}$ dissertation, University of Wales, Newport).

Chapman, R. \& Wylie, A. 2016. Evidential Reasoning in Archaeology. London: Bloomsbury.

Clay, P. 2006. The Neolithic and Early to Middle Bronze Age. In: N. Cooper, ed. The Archaeology of the East Midlands: An Archaeological Resource Assessment and Research Agenda (Leicester Archaeology Monograph 13). Leicester: University of Leicester, pp. 69-88.

Crawford, O.G.S. 1923. Air Survey and Archaeology. The Geographical Journal, 61: 342-66.

Creighton, O. \& Rippon, S. 2017. Conquest, Colonisation and the Countryside: Archaeology and the Mid-11th- to Mid12th-Century Rural Landscape. In: C. Dyer \& D. Hadley, eds. Archaeology and the Norman Conquest. Leeds: Society for Medieval Archaeology, pp. 57-87.

Cunliffe, B. 2004. Wessex Cowboys? Oxford Journal of Archaeology, 23: 61-81. https:// doi.org/10.1111/j.1468-0092.2004.00202.x

Curwen, E. \& Curwen, E.. 1923. Sussex Lynchets and their Associated Fieldways. Sussex, Archaeological Collections, 64: 1-65.

Dent, J. 1984. The Yorkshire Dykes. Archaeological Journal, 141: 32-33.

Evans, C. 2009. Fengate Revisited: Further Fen-edge Excavations, Bronze Age Fieldsystems \& Settlement and the Wyman Abbot/Leeds Archives. Cambridge: Cambridge Archaeological Unit.

Field, D. 2008. The Development of an Agricultural Countryside. In: J. Pollard, ed. Prehistoric Britain. Oxford: Blackwell, pp. 202-24.

Fleming, A. 1988. The Dartmoor Reaves: Investigating Prehistoric Land Division. London: Batsford.

Framework Archaeology 2011. Landscape Evolution in the Middle Thames Valley: Heathrow Terminal 5 Excavations, Vol 2. Salisbury: Wessex Archaeology. 
Garrow, D., Gosden, C., Hill, J. \& Bronk Ramsey, C. 2009. Dating Celtic Art: A Major Radiocarbon Dating Programme of Iron Age and Early Roman Metalwork in Britain, Archaeological Journal, 166: 79123. https://doi.org/10.1080/00665983. 2009.11078221

Garton, D., Lear, R.S., Cowgill, J., Firman, R. \& Wright, L. 2008. The Romano-British Landscape of the Sherwood Sandstone of Nottinghamshire: Fieldwalking the Brickwork-Plan Field-Systems. Transactions of the Thornton Society Nottinghamshire, 112: 15-110.

Giles, M. 2007. Good Fences Make Good Neighbours? Exploring the Ladder Enclosures of Late Iron Age East Yorkshire. In: C. Haselgrove \& T. Moore, eds. The Later Iron Age in Britain and Beyond. Oxford: Oxbow Books, pp 23549.

Giles, M. 2012. A Forged Glamour: Landscape, Identity and Material Culture in the Iron Age. Oxford: Oxbow Books.

Gray, H. 1915. English Field Systems. Cambridge (MA): Harvard University Press.

Griffiths, S. 2017. We're All Cultural Historians Now: Revolutions in Understanding Archaeological Theory and Scientific Dating. Radiocarbon, 59: 1347-57. https:// doi.org/10.1017/RDC.2017.20

Guilbert, G. \& Taylor, C. 1992. Grey Ditch, Bradwell, Derbyshire: Excavations. Preliminary Report. Unpublished report. Nottingham: Trent \& Peak Archaeology. Available online at Archaeology Data Service: https://doi.org/10.5284/1023634.

Hadley, D. 2000. The Northern Danelaw: Its Social Structure, c.800-1100. London: Leicester University Press.

Hamilton, W.D., Haselgrove, C. \& Gosden, C. 2015. The Impact of Bayesian Chronologies on the British Iron Age. World Archaeology, 47: 642-60. https://doi. org/10.1080/00438243.2015.1053976

Haselgrove, C. ed. 2017. Cartimandua's Capital? Research and Excavations at and Around the Late Iron Age Royal Site at Stanwick, North Yorkshire, 1981-2004 (Council for British Archaeology Monograph 175). York: Council for British Archaeology.

Hoare, R. 1810. Ancient Wiltshire. Volume 1. London.

Horne, P. \& MacLeod, D. 1995. The Yorkshire Dales Mapping Project: A Report for the National Mapping Programme (Historic England Research Report 68/ 1995). London: RCHME. Available online at: https://research.historicengland. org.uk/Report.aspx?i=15674.

Jay, M., Haselgrove, C., Hamilton, D., Hill, J. D. \& Dent, J. 2012. Chariots and Context: Radiocarbon Dates from Wetwang Slack and the Chronology of the East Yorkshire Iron Age Burial Tradition and Brooch Sequence. Oxford Journal of Archaeology, 31: 161-89. https:// doi.org/10.1111/j.1468-0092.2012.00384.x

Johnston, R. 2005. Pattern Without a Plan: Rethinking the Bronze Age Coaxial Field Systems on Dartmoor, South-West England. Oxford Journal of Archaeology, 24: 1-21. https://doi.org/10.1111/j.1468-0092. 2005.00222.x

Johnston R. 2013. Bronze Age Field and Land Division. In: H. Fokkens \& A. Harding, eds. The Oxford Handbook of the European Bronze Age. Oxford: Oxford University Press, pp. 307-23.

King, A. 1985. Prehistoric Settlement and Land Use in Craven, N. Yorks. In: D. Spratt \& C. Burgess, eds. Upland Settlement in Britain: The Second Millennium $B C$ and After (British Archaeological Reports British Series 143). Oxford: British Archaeological Reports, pp. 117-34.

Lambrick, G. \& Robinson, M. 2009. The Thames Through Time: The Thames Valley in Late Prehistory 1500 BC-AD 50. Oxford: Oxford Archaeology.

Lee, S. \& Bronk Ramey, C. 2012. Development and Application of the Trapezoidal Model for Archaeological Chronologies. Radiocarbon, 54: 107-22. https://doi.org/10.2458/azu_js_rc.v54i1. 12397

Lewis, C. 2006. The Medieval Period (8501500). In: N. Cooper, ed. The Archaeology of the East Midlands: An Archaeological Resource Assessment and Research Agenda (Leicester Archaeology Monograph 13). Leicester: University of Leicester, pp. 185216.

Løvschal, M. 2014. Lines in the Landscape, Boundaries of the Mind: The Emergence of Landscape and Settlement Boundaries in North-Western Europe in the First Millennium $\mathrm{BC}$ (unpublished $\mathrm{PhD}$ dissertation, Aarhus University). 
Løvschal, M. 2020. The Logics of Enclosure: Deep-Time Trajectories in the Spread of Land Tenure Boundaries in Late Prehistoric Northern Europe. Journal of the Royal Anthropological Institute, 26: 365-88. https://doi.org/10.1111/14679655.13252

Mackey, R. \& Manby, T. 2003. The Iron Age in the Yorkshire Region. In: T. Manby, S. Moorhouse \& P. Ottaway, eds. The Archaeology of Yorkshire: An Assessment at the Beginning of the 21st Century. Leeds: Yorkshire Archaeological Society, pp. 117-24.

Manby, T., King, A. \& Vyner, B. 2003. The Neolithic and Bronze Ages: A Time of Early Agriculture. In: T. Manby, S. Moorhouse \& P. Ottaway, eds. The Archaeology of Yorkshire: An Assessment at the Beginning of the 21st Century. Leeds: Yorkshire Archaeological Society, pp. 35-113.

Martin, J., Schuster, J. \& Barclay, A. 2012. Evidence of an Early Bronze Age Field System and Spelt Wheat Growing, Together with an Anglo-Saxon SunkenFeatured Building, at Monkton Road, Minster in Thanet. Archaeologia Cantiana, 132: 43-52.

McOmish, D. 2011. Introduction to Heritage Assets: Field Systems. Swindon: English Heritage.

Moorhouse, S. 2003. Anatomy of the Yorkshire Dales: Decoding the Medieval Landscape. In: T. Manby, S. Moorhouse \& P. Ottaway, eds. The Archaeology of Yorkshire: An Assessment at the Beginning of the 21st Century. Leeds: Yorkshire Archaeological Society, pp. 293-362.

Nielsen, N., Holst, M., Gadd, A. \& Holst, K. 2018. The Layout and Internal Development of Celtic Fields: Structural and Relative Chronological Analyses of Three Danish Field Systems. European Journal of Archaeology, 21(3), 385-410. https://doi.org/10.1017/eaa.2017.56

Nowakowski, J. 2009. Living in the Sands: Bronze Age Gwithian, Cornwall. In: M. Allen, N. Sharples \& T. O'Connor, eds. Land and People: Papers in Memory of John G. Evans. Oxford: The Prehistoric Society \& Oxbow Books, pp. 115-25.

Oosthuizen, S. 2013. Tradition and Transformation in Anglo-Saxon England: Archaeology, Common Rights and Landscape. London: Bloomsbury.
Reimer, P., Bard, E., Bayliss, A., Beck, J., Blackwell, P., Bronk Ramsey, C. et al. 2013. IntCal13 and Marine13 Radiocarbon Age Calibration Curves 0-50,000 years cal BP. Radiocarbon, 55, 1896-87. https://doi. org/10.2458/azu_js_rc.55.16947

Richardson, J. 2011. Bronze Age Cremations, Iron Age and Roman Settlement and Early Medieval Inhumations at the Langeled Receiving Facilities, Easington, East Riding of Yorkshire. Yorkshire Archaeological Journal, 83: 59-100. https://doi.org/10. 1179/008442711X13033963454408

Rippon, S., Smart, C. \& Pears, B. 2015. The Fields of Britannia. Oxford: Oxford University Press.

Roberts, B. \& Wrathmell, S. 2002. Region and Place: A Study of English Rural Settlement. London: English Heritage.

Rylatt, J. \& Bevan, B. 2007. Realigning The World: Pit Alignments and Their Landscape Context. In: C. Haselgrove \& T. Moore, eds. The Later Iron Age in Britain and Beyond. Oxford: Oxbow Books, pp. 219-23.

Sharples, N. 2010. Social Relations in Later Prehistory: Wessex in the First Millennium $B C$. Oxford: Oxford University Press.

Spratt, D. 1988. Linear Earthworks on the Tabular Hills, Northeast Yorkshire. Sheffield: University of Sheffield.

Ten Harkel, L., Franconi, T. \& Gosden, C. 2017. Fields, Ritual and Religion: Holistic Approaches to the Rural Landscape in Long-Term Perspective (c. 1500 BC-AD 1086). Oxford Journal of Archaeology, 36: 413-37. https://doi.org/10.1111/ojoa.12122

Thomas, R. 1997. Land, Kinship Relations and the Rise of Enclosed Settlement in First Millennium BC Britain. Oxford Journal of Archaeology, 16: 211-18. https:// doi.org/10.1111/1468-0092.00035

Toms, H. 1925. Bronze Age or Earlier Lynchets. Proceedings of the Dorset Natural History and Archaeological Society, 46: 88100.

Vervust, S., Kinnaird, T., Herring, P. \& Turner, S. 2020. Optically Stimulated Luminescence Profiling and Dating of Earthworks: The Creation and Development Of Prehistoric Field Boundaries at Bosigran, Cornwall. Antiquity, 94: 420-36. https://doi. org/10.15184/aqy.2019.138

Waterbolk, H. 1971. Working with Radiocarbon Dates. Proceedings of the 
Prehistoric Society, 37: 15-33. https://doi. org/10.1017/S0079497X00012548

Whittle, A., Healy, F. \& Bayliss, A. 2011. Gathering Time: Dating the Early Neolithic Enclosures of Southern Britain and Ireland. Oxford: Oxbow Books.

Whitefield, A. 2017. Neolithic 'Celtic' Fields? A Reinterpretation of the Chronological Evidence from Céide Fields in Northwestern Ireland. European Journal of Archaeology, 20(2): 257-79. https://doi. org/10.1017/S20.1260.506.

Willis, S. 2006. The Later Bronze Age and Iron Age. In: N. Cooper, ed. The Archaeology of the East Midlands: An Archaeological Resource Assessment and Research Agenda (Leicester Archaeology Monograph 13). Leicester: University of Leicester, pp. 89-136.

Wordie, J. 1983. The Chronology of English Enclosure, 1500-1914. The Economic History Review, 36: 483-505.

Yates, D. 2007. Land, Power and Prestige: Bronze Age Field Systems in Southern England. Oxford: Oxbow Books.

\section{Biographical Notes}

Seren Griffiths is Reader in Public Heritage and Archaeological Science at Manchester Metropolitan University. She researches public archaeology and heritage practice using interdisciplinary methods, specializing in 'prehistory' and archaeological science. She is PI of the AHRC-funded project 'Third and fourth millennia Ireland and Britain: a history of major social change explored' (project 'TIME'). She is Co-PI of the Irish Research Council and AHRCfunded 'Project Radiocarbon'. She is a 2020 21 BBC/AHRC New Generation Thinker.

Address: Department of History, Politics and Philosophy, Manchester Metropolitan University, Geoffrey Manton Building, 4 Rosamond Street West, Manchester M15 6LL UK. [email: seren.griffiths@mmu.ac. uk]. ORCID: https://orcid.org/00000001-5168-9897.
Robert Johnston is Senior Lecturer in Landscape Archaeology at the University of Sheffield. He has published articles and edited books on aspects of landscape archaeology and later prehistory in Britain and north-western Europe. He currently researches landscape transformations in western Britain.

Address: Department of Archaeology, University of Sheffield, Minalloy House, 10-16 Regent Street, Sheffield S1 3NJ, UK. [email: r.johnston@sheffield.ac.uk]

Rowan May works for ArcHeritage, part of the York Archaeological Trust, as a field officer and researcher. Her responsibilities include historic and archaeological research for desk-based assessments, environmental impact assessments, heritage statements, and conservation management plans, as well as landscape survey and excavation. Her research interests in historical archaeology include mining and the steel and iron industries, and urban and rural domestic sites.

Address: ArcHeritage, 54 Campo Lane, Sheffield S1 2EG, UK. [email: rmay@ yorkat.co.uk].

David $\mathrm{McOmish}$ is a senior policy adviser for Historic England specializing in landscape research. $\mathrm{He}$ is also the lead specialist on HE's programme of urban characterization survey. He has published widely on multi-period landscapes, including on the archaeology of Salisbury Plain, and evidence for land divisions across England.

Address: Historic England, 37 Tanner Row, York YO1 6WP, UK. [email: david. mcomish@historicengland,org.uk]. 
Peter Marshall works in Historic England's Policy \& Evidence Department as part of the Scientific Dating Team, coordinating the programme of commissioned radiocarbon dating. He has been involved in many key archaeological projects providing precise chronologies to understand past human activities and how landscapes have changed.

Address: Historic England, Cannon Bridge House, 23 Dowgate Hill, London EC4R 2YA, UK. [email: peter.marshall@historicengland,org.uk]. ORCID: https://orcid.org/00000002-1949-7702.

Jonathan Last is an archaeologist specializing in prehistory. He has worked in various roles for English Heritage and Historic England since 2001. He is currently Landscape Strategy Adviser in the National Specialist Services team.
Address: Historic England, Fort Cumberland, Fort Cumberland Road, Portsmouth P04 9LD, UK. [email: jonathan.last@historicengland,org.uk].

Alex Bayliss leads on all scientific dating activity for Historic England, including development of corporate policy and national standards. She specializes in constructing precise chronologies for archaeological sites and finds through the statistical modelling of radiocarbon dates.

Address: Historic England, Cannon Bridge House, 23 Dowgate Hill, London EC4R 2YA, UK, and Biological and Environmental Sciences, University of Stirling, Stirling FK9 4LA, UK. [email: alex.bayliss@historicengland,org.uk].

ORCID: https://orcid.org/0000-00032782-1979.

\section{La démarcation du territoire: aspects temporels de la division des terres dans le nord des Midlands et le Yorkshire en Angleterre}

La parcellisation des terres est omniprésente dans la campagne anglaise. Les limites de champs, enclos, alignements de fosses et autres éléments de démarcation du territoire ont servi à le transformer et à le délimiter pendant des millénaires. Cependant, alors que ces divisions sont essentielles pour appréhender les mécanismes de l'économie et de l'approvisionnement, l'organisation du mode d'occupation des terres et de la propriété ainsi que la structure sociale et lidentité des communautés, l'bistoire de ces parcelles demeure nébuleuse. Les auteurs de cet article présentent, pour la première fois, une chronologie bayésienne fiable des éléments de démarcation du territoire durant trois millénaires dans une région d'Angleterre. Cette approche novatrice leur permet d'examiner l'évolution du paysage sur la longue durée et de démontrer l'ampleur inattendue des divisions soi-disant "préhistoriques " mais plus récentes qui correspond sans doute aux débuts d'une hiérarchisation sociale croissante. Translation by Madeleine Hummler

Mots-clés: démarcation du territoire, parcellisation, modélisation bayésienne, transformation à long terme, radiocarbone

\section{Die Aufteilung des Landes: Aspekte der Chronologie von Feldanlagen in den nördlichen Midlands und Yorkshire in England}

Fast überall in der englischen Landschaft stößt man auf Spuren von verschiedenen Feldanlagen. Seit Jahrtausenden wurden Feldgrenzen, Gehege, lineare Grubenreiben und andere Einrichtungen errichtet, um die Landschaft zu gestalten und abzugrenzen. Obschon diese Landbereiche für das Verständnis der 
Wirtschaft und der Versorgung der Ernäbrung, der Gliederung der Pachtwirtschaft und der Landsitze sowie der Sozialstruktur und Identität der Gemeinschaften entscheidend sind, bleibt ibre Nutzungsgeschichte unklar. Der vorliegende Artikel ist eine erste Veröffentlichung einer solider Bayesschen Chronologie der Feldanlagen, die währen drei Jahrtausende in einer Gegend von England errichtet wurden. Dieser innovative Ansatz ermöglicht es, die langfristigen Veränderungen in der Landschaft zu untersuchen und das unerwartete Ausmaß der sogenannten "vorgeschichtlichen" Feldanlagen zu dokumentieren. Letzteres entspricht wabrscheinlich dem Beginn einer zunehmenden sozialen Hierarchisierung. Translation by Madeleine Hummler

Stichworte: Landaufteilung, Feldanlagen, Bayessche Modellierung, langfristige Veränderungen, Radiokarbon 